\title{
Snow Stable Isotope Composition Variability Related to the Upper Mendoza River Basin Hypsometry
}

\author{
Sebastián A. Crespo ${ }^{1,2^{*}}$, Julieta N. Aranibar ${ }^{1,3}$, Gonzalo Navarro ${ }^{4}$ \\ ${ }^{1}$ Argentinean Snow, Glaciers and Environmental Research Institute (IANIGLA), Conicet, CCT-Mendoza \\ (CP5500), Mendoza, Argentina \\ ${ }^{2}$ Institute of Geography, Faculty of Marine Sciences and Geography, Pontificia Universidad Católica de \\ Valparaíso, Valparaíso, Chile. \\ ${ }^{3}$ Faculty of Exact and Natural Sciences, National University of Cuyo, Mendoza, Argentina \\ ${ }^{4}$ Faculty of Engineering-Geology, Andrés Bello University, Viña del Mar, Chile
}

\author{
*Corresponding Author: Sebastián Crespo, Argentinean Snow, Glaciers and Environmental Research \\ Institute (IANIGLA), Conicet, CCT-Mendoza (CP5500), Mendoza, Argentina. \\ Email: sebacrespo.oliva@gmail.com
}

\begin{abstract}
The water supply of the northern oasis of the Mendoza province, in the central western of Argentina, depends mainly on the melting of precipitated and accumulated snow during the winter, which supplies water for domestic, industrial and energy consumption to 64\% of the provincial population (more than 1.2 million inhabitants). The solid precipitation stable isotopes composition in mountain regions is affected by isotopic fractionation processes generated by continentally effects, temperature, evaporation during precipitation and isotopic elution phenomena during melting, among others, complicating efforts to quantify sources using stable isotopes as natural tracers. The aim of this work was to evaluate the stable isotopes composition of snowfall in an altitude gradient in the Cordillera Principal, Upper Mendoza River basin. We did not find an altitude effect on stable isotope composition of snow, widely reported in previous studies. Variability was related to the origin of precipitation events. These results validate the use of stable isotopes as tracers of different water sources as glaciers, permafrost, groundwater or snow in Cordillera Principal, to quantify contributions from different sources to riverflow.
\end{abstract}

Keywords: stable isotopes, snow, Cordillera Principal, Mendoza River

\section{INTRODUCTION}

The predicted near surface warming under the influence of increasing levels of greenhouse gases in the atmosphere will be particularly greater in mountain regions (Bradley et al., 2004), with important consequences for the hydrological cycle, particularly in regions where water supply is dominated by the melting of snow and ice, as is the case of the irrigated oases in the Mendoza province (Masiokas et al., 2013). The high glacial melt rates documented in recent decades at global (WRCP, 2009; wgms, 2013) and regional levels (Leiva 1999; Bown et al., 2008) corroborates this increase in the global average temperature, since the industrial revolution. With deeper expected increases in temperatures and droughts for the region (Bradley et al., 2004; Corripio et al., 2007; Gonzalez-Reyes et al., 2017), it is important to monitor the hydrological evolution, including changes in the relative importance of different water sources to river flows. Water stable isotopes, offers an important tool to trace the different water inputs to a river in a basin.

Isotope fractionation is responsible for the changes in the water stable isotope composition when change from one phase to another (Hoefs, 2015). In the hydrologic cycle, water vapor has as its main source oceanic water, from which much of it evaporates, moving towards higher latitudes and altitudes where it cools and condenses precipitating in the oceans. Another part of the vapor advances towards the continent precipitating and forming superficial and subterranean waters. During the condensation process, which results in the precipitations, the fraction of vapor remaining in the air is progressively impoverished at ${ }^{18} \mathrm{O}$ and ${ }^{2} \mathrm{H}$, whereby the values of $\delta^{18} \mathrm{O}$ and $\delta^{2} \mathrm{H}$ of the water vapor become progressively more depleted as precipitation occurs. This is because, as atmospheric humidity cools, 
the heavy molecules condense more easily and the residual vapor contains less and less heavy isotopes. In this way, the meteoric waters leave a characteristic mark, fundamental for the studies of waters (Clark and Fritz, 1997).

In mountains, particularly, isotope fractionation is associated to altitudinal gradients, in a process similar to a Rayleigh fractionation, caused by the preferential precipitation of heavy isotopes in low altitudes, when moist air masses are forced to ascend by these geological barriers. The consequence is a gradient of decreasing natural abundance of heavy isotopes with increasing altitude, observed in many mountain areas of the world (Mariani et al., 2014; Windhorst et al., 2013; Poage and Chamberlain, 2001; Schotterer et al., 1997; Niewodniczanki et al., 1981; Siegenthaler and Oeschger, 1980). Generally, the $\delta^{18} \mathrm{O}$ impoverishment, varies between -0.15 to $-0.5 \%$ per $100 \mathrm{~m}$ increase in altitude, with a corresponding -1 to $-4 \% \delta^{2} \mathrm{H}$ value decrease (Clark and Fritz, 1997). This altitudinal effect is related to the temperature, since condensation is produced with the decrease of the temperature, while altitude increases. Because of the decrease in pressure with altitude $(-1.2 \%$ per 100 $\mathrm{m}$; Mook, 2002), a lowering of the temperature is required to precipitate than in the case of isobaric condensation, to reach saturated water vapor pressure. This force the precipitation occurrence in a cooler environment and more isotopically depleted signatures in snow are expected to be linked to hypsometry increase.

Stable isotopes and ions are useful natural tracers of snow, glacial, groundwater and rains in the study region (Crespo et al., 2017), showing a clear differentiation among these different water sources. However, the expected variability of the isotopic composition of snow, given by fractionation during the evolution of atmospheric moisture along its path from oceans to precipitation sites, presents a challenge to the application of these tracers in snow tracing for the leeward side of the Andes. Moisture is derived from the Pacific, which ascends the Andes in the windward side of the mountains, in the Chilean Andes side, where a Rayleigh type fractionation occurs (Rozanski and Araguás, 1995; Ohlanders et al., 2013). This dynamic change when precipitation reaches the leeward side, in the Argentinean side of the Andes, where other processes may affect stable isotope composition of snow, which are expected to be unrelated to altitude (Crespo et al., 2017).

This work seeks to evaluate the relationship between altitude and stable isotope composition of snow in the leeward side of the Andes, to use stable isotopes as tracers of snow contributions to the tributaries of the Cordillera Principal. In order to test this relationship, we sampled snow that had precipitated in different altitudinal levels, and determined the stable isotope composition of the samples.

With this characterization, we expected to reach a more complete knowledge of each water component in the mountainous hydrological cycle, complementing the study of basin contributions with different types of glaciers, snow and groundwater developed in Crespo et al. (2017). This knowledge will contribute information to evaluate water scarcity mitigation policies in the near future.

\section{Methodology}

\subsection{Study Area}

The main criterion to select the study site was to analyze a basin that was important for the population water supply. The Mendoza River supplies more than one million people with only $49 \mathrm{~m}^{3} / \mathrm{s}$ of average monthly flow (Masiokas et al., 2013). Vitiviniculture represents the second economic activity of the province after the hydrocarbon industry (Corripio et al., 2007) and relies on irrigation. Between 1986 and 2003, $62 \%$ of the energy for domestic use was generated by the runoff of the mountain rivers (Masiokas et al., 2006). These data indicates that the socio-economic development and the subsistence of the central-western region of Argentina are strongly linked to the melting waters of the Andes.

The Mendoza River flow derives mainly from the winter snowmelt, which is strongly influenced by high interannual variability (Minetti et al., 1986; Bruniard, 1994; Compagnucci and Vargas, 1998; Masiokas et al., 2006). In these latitudes the maximum amount of precipitation is observed in the windward, in the Chilean side of the Cordillera Principal mountain range. Rainfall increases from 300 $\mathrm{mm}$ per year on the Chilean coast to over $700 \mathrm{~mm}$ above 2885 masl in El Portillo, Chile, a few kilometers before the international limit. From the Argentine-Chilean boundary to the east, precipitation amounts decline rapidly, generating a large gradient while they cross the mountains, with 
less than $300 \mathrm{~mm}$ in the inmediate leeward slope, to less than $50 \mathrm{~mm}$ in Uspallata, at $1891 \mathrm{~m}$ asl (Viale and Nuñez, 2011).

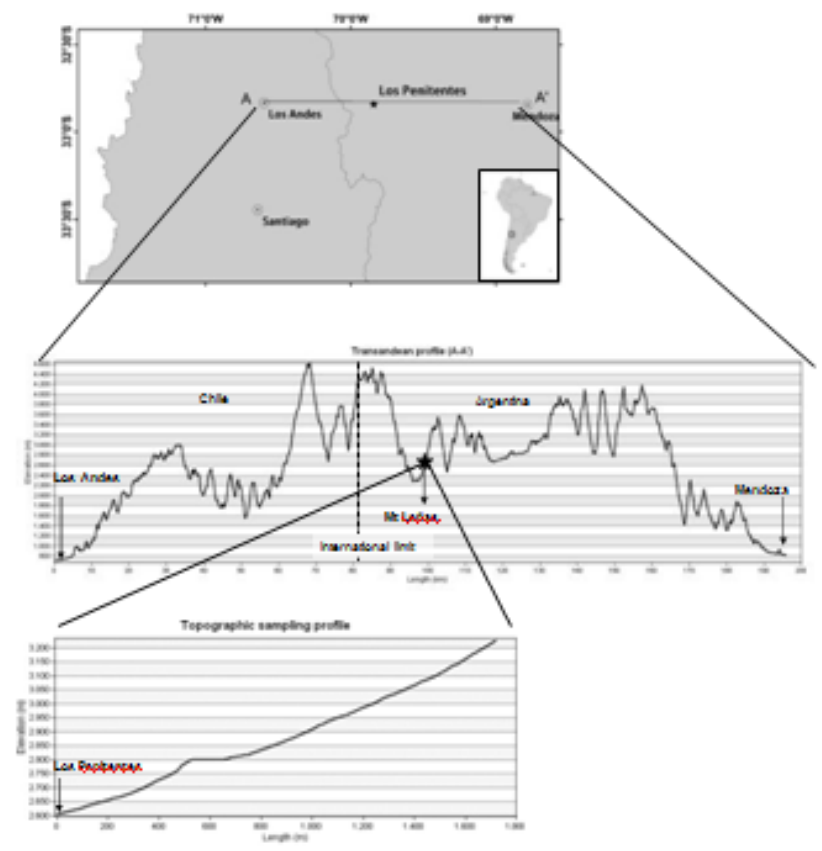

Figure1. Site map and elevation profile of the sampling altitudinal transect developed at the Mt. Leñas

\subsection{Snow Sampling in Cordillera Principal}

Isotopic composition modifications occur during continental transport, precipitation, accumulation period and / or water delivery, and thus the snow isotopic composition studied (eg, Ohlanders et al., 2013; Dietermann and Weiler, 2013; Rodriguez et al., 2014; Crespo et al., 2017) are not known with precision, especially concerning the stable isotopes composition changes related to altitudinal effect. Considering the precipitation gradient along the West-East direction explained before, the sampling design includes snow samples taken in an altitudinal transect (Fig. 1) located on Mt. Leñas $\left(32^{\circ} 49\right.$ '30.24 "S, 69 ${ }^{\circ} 50^{\prime}$ '03.06"W), in the Cordillera Principal geological province, after two storm events during the winter 2016. This sampling design is coincident with the accumulation period of the winter snowfall.

The samples were collected in $15 \mathrm{~mL}$ falcon tubes, sampling the snow accumulated in two snowstorms, on June $25^{\text {th }}$ and July $2^{\text {nd }}, 2016$. To avoid fractionation, samples were taken early in the morning, before temperatures were above $0^{\circ}$ Celsius and sealed with a cohesive thermoplastic (PARAFILM). They were taken along an $1800 \mathrm{~m}$ transect, at $100 \mathrm{~m}$ altitudinal intervals, in seven sites located from 3214 to $2614 \mathrm{~m}$ asl. To prevent fractionation during sublimation and snow melt as much as possible, a minimum of time should elapse between each sampling at each altitudinal level sampled. Therefore, samples were taken by skiing and the temperature of the snow was recorded with an infrared thermometer, where the temperature of the snow sampled was never warmer than $-1^{\circ} \mathrm{C}$.

\subsection{Chemical Analysis}

Isotopic analyzes were determined by laser spectrometry using the T-LWIA-45-EP (Triple Laser Water Isotope Analizer) of Los Gatos Research at the Stable Isotope Laboratory, Andrés Bello University. The measurements presents an error lower than 0.80 for $\delta^{2} \mathrm{H} \%$ and 0.10 for $\delta^{18} \mathrm{O} \%$, according to the Vienna Standard Mean Ocean Water (VSMOW) (Table S1, Supplementary data).

\subsection{Statistical Analysis of the Altitudinal Influence on the Content of Water Stable Isotopes}

The effect of altitude on the isotopic compositions $\left(\delta^{2} \mathrm{H}, \delta^{18} \mathrm{O}\right.$ and deuterium excess) of snow was analyzed with a generalized linear analysis (Burnham and Anderson, 2002), in R statistical environment (R Core Team, 2013).

\subsection{Modeling Retro-Trajectories of Air Masses}

In order to determine the origin of the air masses that cause precipitation in the Mt. Leñas, a data analysis is carried out to obtain the trajectory of the precipitations analyzed: June $25^{\text {th }}$ and July $2^{\text {nd }}$, 2016. 
The modeling is based on a retro-trajectory analysis of the air masses that precipitate in the study area, using the free-use software HYSPLIT (Hybrid Single Particle Lagrangian Integrated Trajectory, (Draxler and Hess, 1998), a resource shared by the Air Resources Laboratory (ARL) of NOAA (National Oceanic and Atmospheric Administration).

A daily analysis of the data was carried out using the Global Forecast System (GFS) database with a quarter degree resolution, obtaining a 72 hours retro-trajectory, in a constant pressure test (approximately $520 \mathrm{mbar}$, equivalent to 1500 masl), running the model at $12 \mathrm{pm}$ (local time) each day.

\section{RESUlts}

\subsection{Water Stable Isotopes Composition}

Firstly, a difference in the isotopic composition in each storm event was observed, with lower $\delta^{2} \mathrm{H}$ and $\delta^{18} \mathrm{O}$ values in the later one (B). The snow isotopic composition represents a Local Meteoric Water Line (LMWL) following the equation: $\delta^{2} \mathrm{H}=7.52 \delta^{18} \mathrm{O}+2.66$, with an $\mathrm{R}^{2}=0.99$. This trend line is slight different, especially in the intercept, than the Global Meteoric Water Line (GMWL) defined by Craig (1961), which follows the equation: $\delta^{2} \mathrm{H}=8 \delta^{18} \mathrm{O}+10$ (Fig. 2).

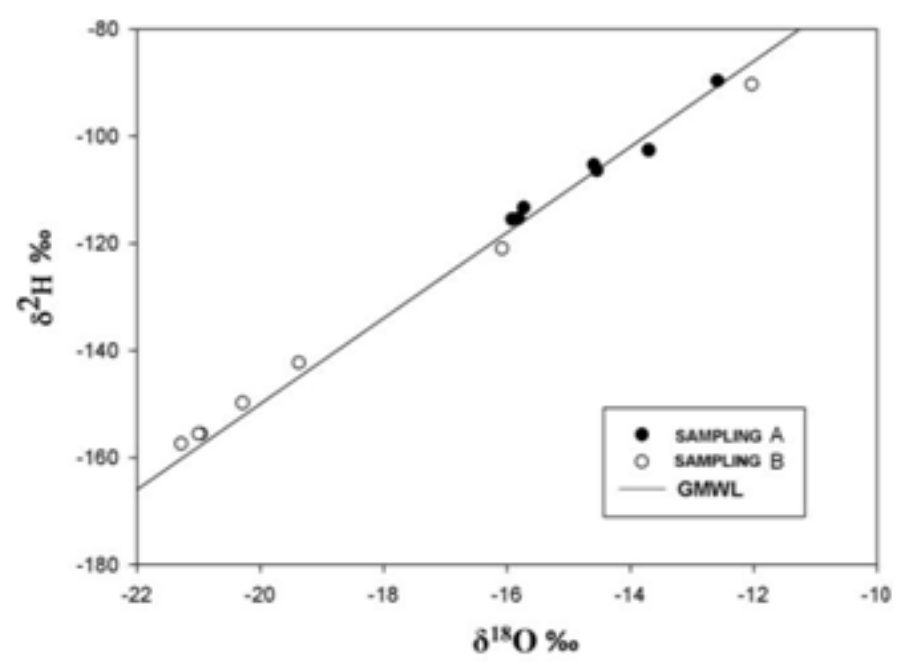

Figure2. Different precipitation events water stable isotope composition scatter plot. Sampling A: June $26^{\text {th }}$ and sampling B: July $2^{\text {nd }}$. GMWL: global meteoric water line

\subsection{Isotopic Composition and Hypsometry Analysis}

As can be observed in figures 3 to 6 , there was no evident relationship between the isotopic composition and the hypsometric differences of each sampling.

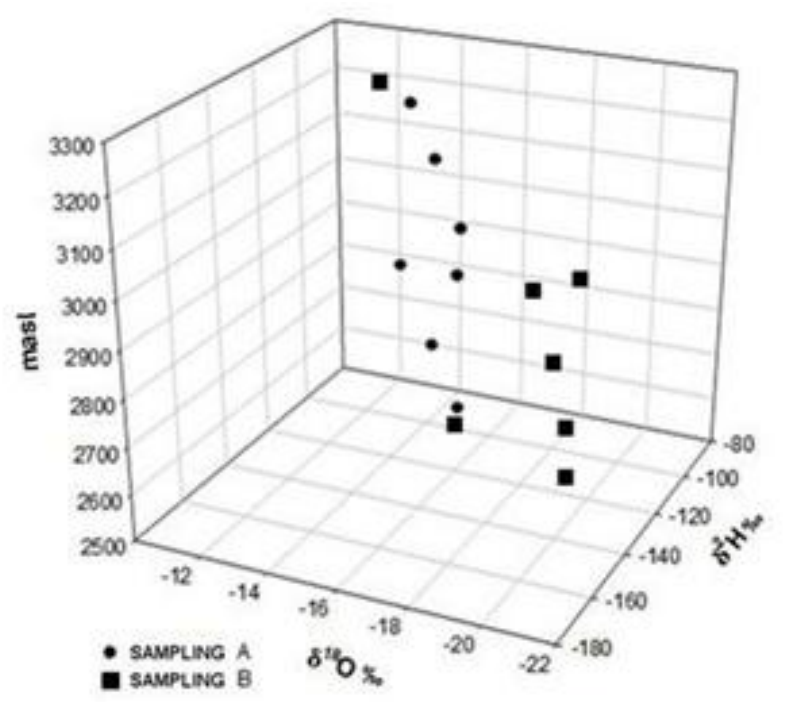

Figure3. $\delta^{2} H$ and $\delta^{18} O$ composition for each altitudinal level scatter plot 


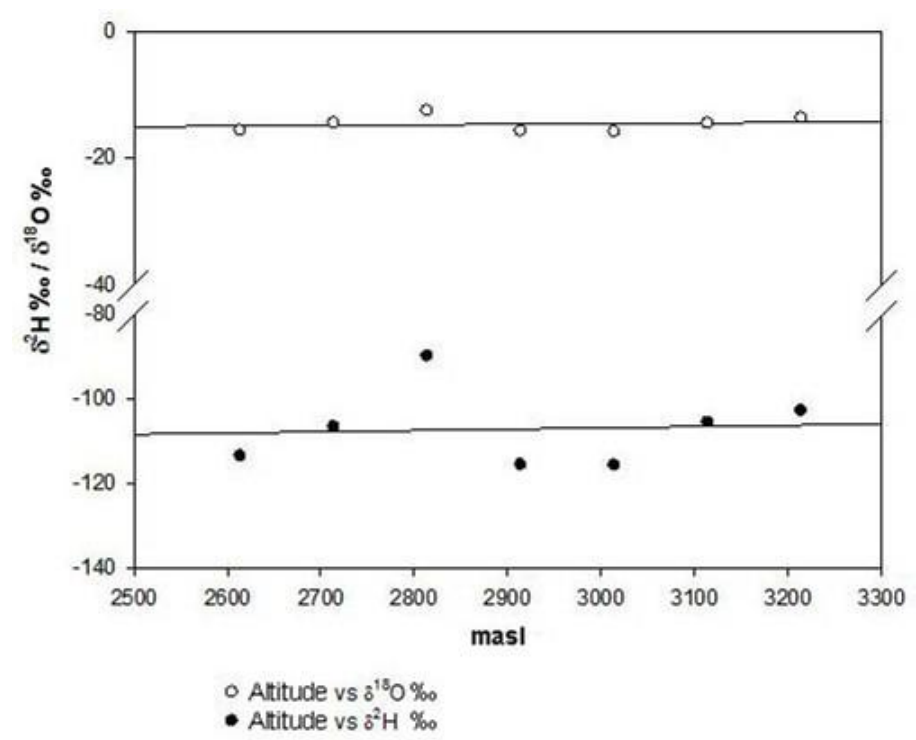

Figure4. Heavy stable isotopes composition dispersion plot with respect to altitude, for samples collected after the June $25^{\text {th }}$ storm

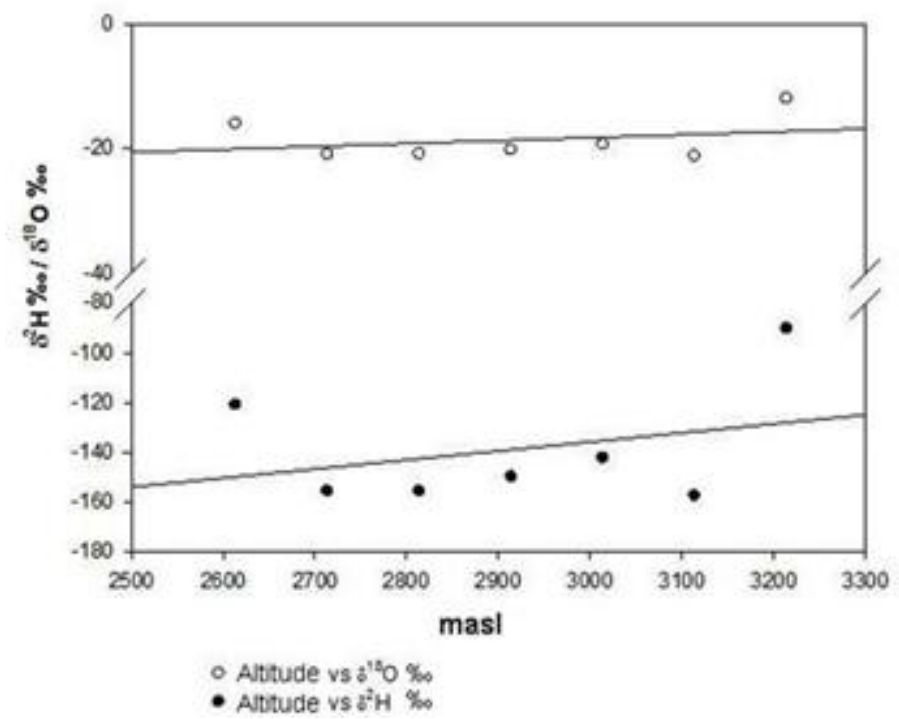

Figure5. Heavy stable isotopes composition dispersion plot with respect to altitude, for samples collected after the July $2^{\text {nd }}$ storm

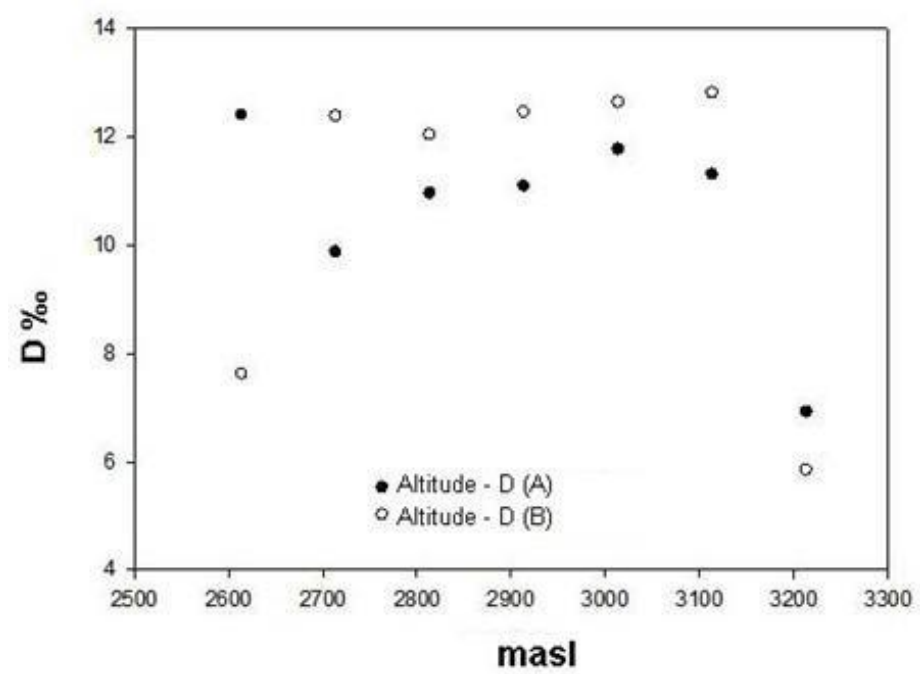

Figure6. Deuterium excess $(D)$ dispersion plot relative to altitude, for samples collected after the June $25^{\text {th }}$ storm (A) and July $2^{\text {nd }}(B)$ 


\subsection{Statistical Analysis}

The results of the generalized linear analysis validate this prior assumption. Instead of an altitude effect on the isotopic composition of snow, a significant temporal influence was found. As can be observed in Table 1 , the $\delta^{2} \mathrm{H}$ and $\delta^{18} \mathrm{O}$ values are linked to the different storms events and not to altitude. Significant differences were observed for both, $\delta^{2} \mathrm{H} \%$ and $\delta^{18} \mathrm{O} \%$, associated to the storm event date (Date).

Table1. Generalized lineal model summary for stable isotopes and deuterium excess response variables according to date and altitude factors. Significant variables are marked in bold. The codes represent the pvalues as: ** for 0.01 and * for 0.05

\begin{tabular}{|c|c|c|c|c|c|}
\hline Variable & Estimate & Std. Error & t value & $\operatorname{Pr}(>|\mathbf{t}|)$ & p \\
\hline \multicolumn{6}{|l|}{$\delta^{18} \mathrm{O} \%$} \\
\hline Altitude & 0.002827 & 0.003517 & 0.804 & 0.4385 & \\
\hline Date & -4.017 & 1.406682 & -2.856 & 0.0156 & $*$ \\
\hline \multicolumn{6}{|l|}{$\mathrm{R}^{2} 0.44$} \\
\hline \multicolumn{6}{|l|}{$\delta^{2} \mathrm{H} \%$} \\
\hline Altitude & 0.01964 & 0.02547 & 0.771 & 0.45684 & \\
\hline Date & $\mathbf{- 3 1 . 9 2 5 7}$ & 10.18827 & -3.134 & 0.00952 & $* *$ \\
\hline \multicolumn{6}{|l|}{$\mathrm{R}^{2} 0.49$} \\
\hline \multicolumn{6}{|c|}{ Deuterium excess } \\
\hline Altitude & -0.002971 & 0.003208 & -0.926 & 0.3743 & \\
\hline Date & 0.210286 & 1.283387 & 0.164 & 0.8728 & \\
\hline $\mathrm{R}^{2} 0.07$ & & & & & \\
\hline
\end{tabular}

\subsection{Air Masses Retro-Trajectory Analysis}

The retro-trajectory analysis of the air masses that precipitate in the study area showed different provenance (Fig. 7).

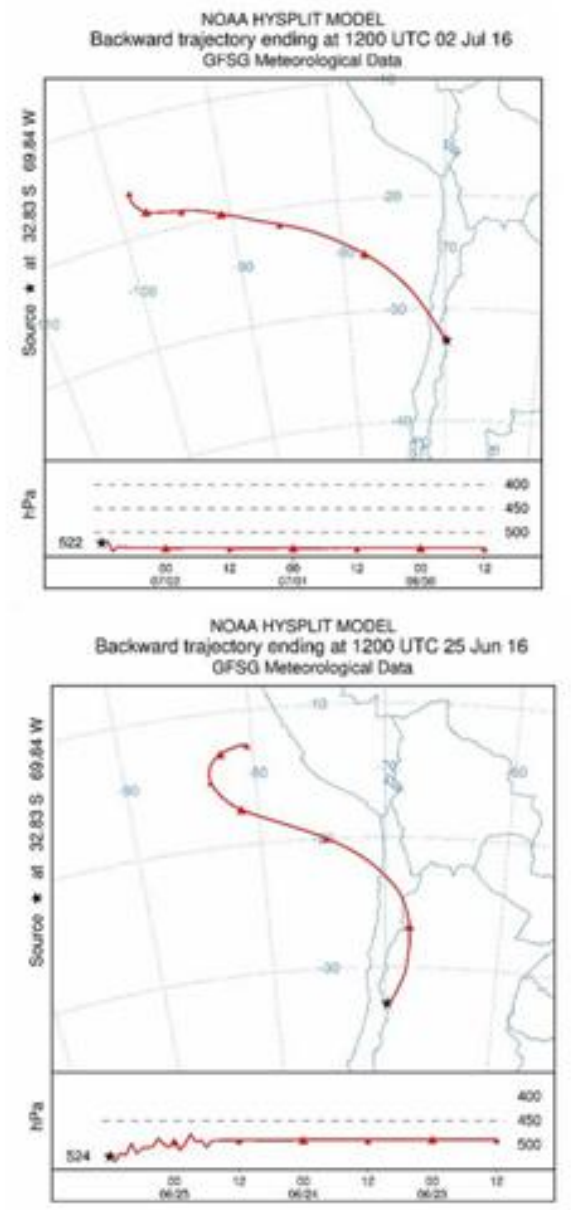

Figure7. HYSPLIT air masses retro-trajectory analysis of the analyzed precipitations: June $25^{\text {th }}$ (down) and July $2^{\text {nd }}, 2016$ (upper) 


\section{DISCUSSION}

Although many studies have found altitudinal effects in the precipitation composition of $\delta^{18} \mathrm{O}$ in the Alps, in the order of -0.17 / $-0.2 \%$ every 100 m (Mariani et al., 2014; Windhorst et al., 2013; Poage and Chamberlain, 2001; Schotterer et al., 1997; Siegenthaler and Oeschger, 1980), the slope of the altitudinal effect is variable (from $0.1 \%$ to $0.6 \%$ / $100 \mathrm{~m}$ ), depending on the temperature and isotopic fractionation during condensation, altitude, orographic characteristics, moisture source (Horvatinčić et al., 2005), and the trajectories of the air masses (Aouad-Rizk et al., 2005). In the Cordillera Principal geological province, the stable isotope values of streams and rivers showed a slight altitudinal effect in a previous study, attributed to seasonality and changes in the relative contribution from different water sources to streams (Crespo et al., 2017).

The rain out effect or the preferential discharge of heavy isotopes during the advance of air mass in the windward (Chilean side) is more important than on the studied basin here, located in the leeward side. Once on the leeward side, the altitude decreases as the air masses move eastward, then other effects have more influence on the isotopic compositions. The effects are reflected in this analysis of the isotopic composition of solid precipitation, corresponding to two storm events occurred in the winter season of 2016, where no effects of altitude on snow stable isotope composition were found. The difference in the isotopic composition in each storm event observed, with lower $\delta^{2} \mathrm{H}$ and $\delta^{18} \mathrm{O}$ values in the later storm event (July 2nd), can be related to the different air mass trajectory as can be observed in the HYSPLIT model (Fig. 7).

\section{CONCLUSIONS}

According to the isotopic analysis carried out in different storm events along the studied altitudinal gradient, it is concluded there is no significant influence of altitude on the stable isotope composition of snow in this area of the leeward side of Cordillera Principal at $32^{\circ} \mathrm{S}$, which feeds the Mendoza River. Even with this space and time limited study, in proportion to the Andes mountain range scale, this work reinforces the use of stable isotope compositions as tracers of different water sources contributions to the upper Mendoza River, as was observed in Crespo et al. (2017).

\section{SUPPORT}

The resources for carrying out the campaigns came from authors personal contributions and the isotopic analysis were financed by the Institute of Geography, Pontificia Universidad Católica de Valparaíso. Conicet postdoctoral scholarship.

\section{ACKNOWLEDGEMENTS}

To Francisco Fernandoy, Ivonne Quintanilla and Ariel Muñoz for helping with the isotopic analysis in the Laboratory of Stable Isotopes, Andrés Bello University, Chile. To Leonardo Crespo, Matías Cara and José M. Oliva for the fieldwork help. To Conicet, for the postdoctoral scholarship.

\section{REFERENCES}

Aouad-Rizk A., Job J.L., Najem W., Travi Y., Blavoux B. and Gourcy L. 2005. Oxygen-18 and deuterium contents over Mount Lebanon related to air mass trajectories and local parameters. En: Isotopic composition of precipitation in the Mediterranean Basin in relation to air circulation patterns and climate. IAEA final report 2000-2004, IAEA-TECDOC-1453: 75-82.

Bown F., Rivera A. and Acuña C. 2008. Recent glacier variations at the Aconcagua basin, central Chilean Andes. Annal of Glaciology 48. Pp. 43-48.

Bradley R. S, Keiming F.T and Díaz. 2004. Projected temperature changes along the American cordillera and the planned GCOS network. Geophys. Res. Lett., 31, L16+210, doi: 10.1029/2004GL020229.

Bruniard E. 1994. Los regímenes fluviales de alimentación sólida en la República Argentina. Ensayo de elaboración de un modelo hidroclimático de la vertiente oriental de los Andes. Academia Nacional de Geografía, publicación especial nº7. Buenos Aires.

Burnham K. P. and Anderson D. R. 2002. Model selection and multimodel inference: a practical informationtheoretic approach. Segunda edición. Springer, New York.

Clark I and Fritz P. 1997. Environmental Isotopes in Hydrogeology. Lewis Publishers, New York, 328 p. Compagnucci R, Vargas W. 1998. Interanual variability of the Cuyo rivers streamflow in the Argentinean

Andean mountains and ENSO events. Int. J Climatol., Vol. 18, Pp. 1593-1609. 
Corripio J. G, Purves R. S. and Rivera A. 2007. Modelling climate-change impacts on mountain glaciers and water resources in the Central Dry Andes.

Craig H. 1961. Isotopic Variations in meteoric waters. Science 133, Pp. 1702-1708.

Crespo S, Aranibar J, Gomez L, Schwikowski M, Bruetsch S, Cara L and Villalba R. 2017. Ionic and stable isotope chemistry as indicators of water sources to the Upper Mendoza River Basin, Central Andes of Argentina. Hidrological Sciences Journal. DOI: 10.1080/02626667.2016.1252840

Draxler R and Hess G. 1998. An overview of the HYSPLIT_4 modeling system for trajectories, dispersion, and deposition. Australian Meteorological Magazine 47, Pp. 295-308.

Dietermann N and Weiler M. 2013. Spatial distribution of stable water isotopes in alpine snow cover. Hydrology and Earth System Sciences, Vol. 10, Pp. 2641-2664.

Gonzalez-Reyes A, McPhee J, Le Quesne C., Christie D, Masiokas M, Villalba R, Szejner P, Muñoz A and Crespo S. 2017. Spatio-temporal variations in hydroclimate across the Mediterranean Andes $\left(30^{\circ}-37^{\circ} \mathrm{S}\right)$ since the early 20th century. Journal of Hydrometeorology. DOI: 10.1175/JHM-D-16-0004.1. Available from: http://dx.doi.org/10.1175/JHM-D-16-0004.1

Hoefs J. 2015. Stable isotope geochemistry, 7 ed., Springer International Publishing, Switzerland. ISBN 978-3319-19715-9. DOI 10.1007/978-3-319-19716-6

Horvatinčić N., KrajcarBronić I., Barešić J., Obelić B. and Vidič S. 2005. Tritium and stable isotope distribution in the atmosphere at the coastal region of Croatia. IAEA final report 2000-2004: Isotopic composition of precipitation in the Mediterranean Basin in relation to air circulation patterns and climate. IAEATECDOC-1453: 37-50.

Leiva J.C. 1999. Recent fluctuations of the Argentinean glaciers. Global Planet Change, 22, Pp. 169-177. Mariani I., Eichler A., Jenk T. M., Brönnimann S., Auchmann R., Levenberger M. C. and Schwikowski M.

2014. Temperature and precipitation signal in two Alpine ice cores over the period 1961-2001. Clim. Past, 10, Pp. 1093-1108.

Masiokas M, Villalba R, Luckman B, Le Quesne C and Aravena JC. 2006. Variaciones de la precipitación nívea en los Andes centrales de Argentina y Chile, 1951-2005: Influencias atmosféricas de gran escala e implicancias para los recursos hídricos en la región. Journal of Climate, Vol. 19, Pp. 6334-6352.

Masiokas M., Villalba R., Luckman B., Montaña E., Betman E., Christie D., Le Quesne C. and Mauget S. 2013. Recent and historic Andean Snowpack and Streamflow Variations and Vulnerability to Water Shortages in Central Western Argentina. Climate Vulnerability: Understanding and Addressing Threats to Essential Resources. Elseiver Inc., Academic Press, Pp. 213-227.

Minetti J, Poblete A, Carletto M, Barbieri P and Sierra E. 1986. El régimen de precipitación de San Juan y su entorno. CONICET. San Juan.

Mook, W. G., and J. J. de Vries. 2002. Is topos ambientales en el ciclo hidrol gico: principios y aplicaciones.

Madrid: IGME.

Niewodniczanski J.,Grabczak J., Baranski L and Rzepka J. 1981. The altitude effect on the isotopic composition of snow in high mountains.Journal of Glaciology 27 (95). Pp. 99-111.

Ohlanders N, Rodriguez M and Mc Phee J. 2013. Stable isotope variation in a Central Andean watershed dominated by glacier and snowmelt. Hydrology and Earth System Sciences, Vol. 17, Pp. 1035-1050.

R Core Team. 2013. R: A language and environment for statistical computing. R Foundation for Statistical Computing, Vienna, Austria.ISBN 3-900051-07-0. Disponible desde: http://www.R-project.org.

Rodriguez M., Ohlanders N. and McPhee J. 2014. Estimating glacier and snowmelt contributions to stream flow in a Central Andes catchment in Chile using natural tracers. Hydrology and Earth System Sciences 18.Pp. $1-46$.

Rozanski K. and Araguás L. 1995. Spatial and temporal variability of stable isotope composition over the South American continent, Bull. Inst. Fr. Etud. Andin., 24, Pp. 379-390.

Poage M. and Chamberlain C.P. 2001. Empirical relationships between elevation and the stable isotope composition of precipitation and surface waters: consideration for studies of paleoelevation change. American Journal of Science, Vol. 301, Pp. 1-15.

Schotterer U., Fröhlich K., Gäggeler H.W., Sandjordj S. and Stichler W. 1997. Isotope records from Mongolian and Alpine ice cores as climate indicators, Climatic Change, 36, Pp. 519-530.

Siegenthaler U. and Oeschger H., 1980. Correlation of ${ }^{18} \mathrm{O}$ in precipitation with temperature and altitude, Nature, 285, Pp. 314-317.

Viale M. and Nuñez M. 2011. Climatology of Winter Orographic Precipitation over the Subtropical Central Andes and Associated Synoptic and Regional Characteristics. Journal of Hydrometeorology. Vol. 12, Pp 481-507. 
WCRP. 2009. Scientific knowledge for climate adaptation, mitigation and risk management. World climate research programme achievements.

WGMS. 2013. Glacier Mass Balance Bulletin No. 12 (2010-2011). Zemp, M., Nussbaumer, S. U., Naegeli, K., Gärtner-Roer, I., Paul, F., Hoelzle, M., and Haeberli, W. (eds.), ICSU(WDS)/IUGG(IACS)/UNEP/ UNESCO/WMO, World Glacier Monitoring Service, Zurich, Switzerland, 106 pp., publication based on database version: doi:10.5904/wgms-fog-2013-11.

Windhorst D., Waltz T., Timbe E., Frede H.G. and Breuer L. 2013. Impact of elevation and weather patterns on the isotopic composition of precipitation in a tropical montane rainforest. Hydrology and Earth System Sciences, 17, Pp. 409-419.

\section{SUPPLEMENTARY DATA}

Table S1 Snow stable isotopes composition per altitude and sampling date

\begin{tabular}{|c|c|r|r|r|r|}
\hline SampleN & Date & Altitude $(\mathbf{m})$ & $\boldsymbol{\delta}^{\mathbf{2}} \mathbf{H} \%$ & $\boldsymbol{\delta}^{\mathbf{1 8}} \mathbf{O} \%$ & $\mathbf{d - e x c e s s}$ \\
\hline 1 & $26 / 06 / 2016$ & 3214 & -102.7 & -13.7 & 6.9 \\
\hline 2 & $26 / 06 / 2016$ & 3114 & -105.4 & -14.6 & 11.3 \\
\hline 3 & $26 / 06 / 2016$ & 3014 & -115.6 & -15.9 & 11.7 \\
\hline 4 & $26 / 06 / 2016$ & 2914 & -115.4 & -15.8 & 11.1 \\
\hline 5 & $26 / 06 / 2016$ & 2814 & -89.7 & -12.6 & 10.9 \\
\hline 6 & $26 / 06 / 2016$ & 2714 & -106.4 & -14.5 & 9.9 \\
\hline 7 & $26 / 06 / 2016$ & 2614 & -113.4 & -15.7 & 12.4 \\
\hline 8 & $02 / 07 / 2016$ & 3214 & -90.4 & -12.0 & 5.9 \\
\hline 9 & $02 / 07 / 2016$ & 3114 & -157.4 & -21.3 & 12.8 \\
\hline 10 & $02 / 07 / 2016$ & 3014 & -142.3 & -19.4 & 12.6 \\
\hline 11 & $02 / 07 / 2016$ & 2914 & -149.8 & -20.3 & 12.4 \\
\hline 12 & $02 / 07 / 2016$ & 2814 & -155.6 & -21.0 & 12.0 \\
\hline 13 & $02 / 07 / 2016$ & 2714 & -155.6 & -21.0 & 12.3 \\
\hline 14 & $02 / 07 / 2016$ & 2614 & -121.0 & -16.1 & 7.6 \\
\hline
\end{tabular}

Citation: S. Crespo et al., "Snow Stable Isotope Composition Variability Related to the Upper Mendoza River Basin Hypsometry", International Journal of Advanced Research in Chemical Science (IJARCS), vol. 4, no. 11, pp. 1-9, 2017. http://dx.doi.org/10.20431/2349-0403.0411001

Copyright: (C) 2017 Authors. This is an open-access article distributed under the terms of the Creative Commons Attribution License, which permits unrestricted use, distribution, and reproduction in any medium, provided the original author and source are credited. 